\title{
ANAEROBIC INDUCTION OF SUPEROXIDE DISMUTASE IN ESCHERICHIA COLI BY NITRATE RESPIRATION
}

\author{
KOHICHIRO MIYAKE AND SEIICHI HINO* \\ Botanical Institute, Faculty of Science, Hiroshima University, \\ Naka-ku, Hiroshima 730, Japan \\ * Hiroshima Jogakuin College, Ushida-Higashi 4-chome, \\ Higashi-ku, Hiroshima 730, Japan
}

(Received October 7, 1988)

\begin{abstract}
Previously, we demonstrated that nitrate respiration increases the synthesis of iron-containing superoxide dismutase (Fe SOD) in anaerobically grown Escherichia coli cells. In this study, we developed a system with which the anaerobic induction of Fe SOD by nitrate respiration in E. coli was separated from the induction of the nitrate respiration system. The anaerobic induction of Fe SOD required the presence of both nitrate and an electron donor, and the induction of Fe SOD by nitrate respiration was inhibited by chloramphenicol or riphampicin. When glucose was used as the electron donor, carbonyl cyanide $p$-trifluoro-methoxyphenylhydrazone (FCCP) but not $N, N^{\prime}$-dicyclohexylcarbodiimide (DCCD) inhibited the induction of Fe SOD by nitrate respiration, but when formate was used as the donor, both FCCP and DCCD inhibited the induction of Fe SOD by nitrate respiration.
\end{abstract}

Superoxide dismutase (SOD), which catalyzes dismutation of the superoxide anion radical $\left(\mathrm{O}_{2}{ }^{-}\right)$into $\mathrm{O}_{2}$ and $\mathrm{H}_{2} \mathrm{O}_{2}$, is generally regarded as protecting the cells from oxygen toxicity.

Escherichia coli has three types of SOD: iron-containing SOD (Fe SOD) (1), manganese-containing SOD (Mn SOD) (2), and a SOD with a protein moiety, this is a hybrid of Fe SOD and Mn SOD (hybrid SOD) (3).

We have shown that $E$. coli cells, grown anaerobically by fermentation, had a low level of SOD and contained Fe SOD only (4). We also showed that E. coli cells, grown anaerobically by anaerobic respiration with an electron acceptor such as nitrate, fumarate, dimethyl sulfoxide (DMSO) or trimethylamine $N$-oxide (TMAO), contained increased levels of Fe SOD (5). In addition, it was reported that when $E$.

Address reprint requests to: Dr. Kohichiro Miyake, Botanical Institute, Faculty of Science, Hiroshima University, Naka-ku, Hiroshima 730, Japan. 
coli cells were grown anaerobically by nitrate respiration, Mn SOD and hybrid SOD were also synthesized (4-6). Recently SCHIAvone and Hassan reported that Mn SOD was induced under anaerobic condition when $E$. coli cells were grown in the presence of potassium ferricyanide, copper-cyanide complex, ammonium persulfate or hydrogen peroxide(7). On the other hand, Privalle and Fridovich showed that anaerobically grown E. coli cells had an inactive form of Mn SOD and that the addition of a terminal electron acceptor, such as nitrate or TMAO, increased the amount of inactive Mn SOD in anaerobically grown $E$. coli $(8)$.

Generally speaking, growing cells are not useful for the study of the control mechanism in enzyme synthesis, since selection of the cells with high enzyme may occur during the growth. Therefore, we intended to develop a system with which anaerobic induction of SOD by nitrate respiration is possible with little accompanying cell growth. We also attempted to separate the induction of SOD from the induction of nitrate respiration in E. coli cells. After establishment of the system, we examined the effects of several factors on the anaerobic induction of SOD by nitrate respiration.

\section{MATERIALS AND METHODS}

Bacteria and growth conditions. Escherichia coli $\mathrm{K} 12 \mathrm{~W} 1895$ (Hfr, met) was used in this study.

The composition of the peptone-glucose medium (PSG medium) and the procedure of anaerobic culture were as described previously(4). Cell concentrations were measured in a cuvette with a $10-\mathrm{mm}$ light path using a Hitachi EPO B photometer at $660 \mathrm{~nm}$, and expressed by absorbance as $A_{660}$. An $A_{660}$ value of 1.0 corresponds to $1.6 \mathrm{mg}$ of cell protein per $\mathrm{ml}$.

Short term incubation of cell suspensions. The cells grown anaerobically in PSG medium with $40 \mathrm{~mm} \mathrm{KNO}_{3}$ for $2 \mathrm{~h}$ were harvested by centrifugation and suspended in $40 \mathrm{ml}$ of an incubation mixture containing $0.25 \%$ casamino acids, $10 \mu \mathrm{M} \mathrm{FeCl}, 10 \mu \mathrm{M} \mathrm{MnSO}_{4}, 0.1 \mathrm{M}$ potassium phosphate buffer $(\mathrm{pH} 7.2)$ and other additions such as nitrate. The suspension was added to a $100-\mathrm{ml}$ Sakaguchi-flask, then the gas phase of the flask was changed to pure $\mathrm{N}_{2}\left(\mathrm{O}_{2}\right.$ less than $\left.0.01 \%\right)$. The suspension was incubated for $4 \mathrm{~h}$ at $30^{\circ} \mathrm{C}$ with shaking on a reciprocating shaker at 120 strokes per min with an amplitude of $5 \mathrm{~cm}$.

Assays. Cell-free extracts were prepared by sonic disruption as described previously (4).

SOD activity was estimated by the method of MCCORD and Fridovich (9) with a slight modification (4). One unit of SOD activity is defined as the amount of enzyme which produces $50 \%$ inhibition of cytochrome $c$ reduction. SOD activity was calculated from the results of more than three independent experiments. SOD isozymes were separated by electrophoresis on $7.5 \%$ polyacrylamide gels, then the gels were stained by the method of BeAuchamp and Fridovich (10).

Nitrate reductase ( $\mathrm{NaR}$ ) activity, with methyl viologen (MV) as an electron 
acceptor, was assayed by the method of GAUTHIER et al.(11) with a slight modification. The assay was carried out in an open tube containing $20 \mu \mathrm{mol}$ of $\mathrm{KNO}_{3}, 0.1 \mu \mathrm{mol}$ of methyl viologen, $19 \mu \mathrm{mol}$ of $\mathrm{NaHCO}_{3}, 9 \mu$ mol of sodium dithionite and $100 \mu \mathrm{mol}$ of potassium phosphate buffer $(\mathrm{pH}$ 7.2) in a final volume of $1 \mathrm{ml}$. The reaction was started by adding a freshly prepared solution of sodium dithionite in $\mathrm{NaHCO}_{3}$, and the reaction mixture was incubated for $10 \mathrm{~min}$ at $30^{\circ} \mathrm{C}$. One unit of $\mathrm{NaR}$ activity was defined as the amount of enzyme that produces $1 \mu \mathrm{mol}$ of nitrite in $10 \mathrm{~min}$. Nitrite was measured by the diazo-coupling method as described previously (4).

Protein was measured by the biuret reaction according to the method of ITZHAKI and GILL (12).

\section{RESULTS}

Effect of nitrate on anaerobic SOD synthesis in growing cells

We reported that when $E$. coli cells were cultured anaerobically for $18 \mathrm{~h}$, cellular SOD activity increased about 4 -fold by the operation of nitrate respiration(4). In that study, we did not examine the kinetics of cell growth or enzyme synthesis. In the present study, the cells, grown anaerobically for $18 \mathrm{~h}$ by fermentation, were harvested, inoculated in the fresh medium and cultured anaerobically for $4 \mathrm{~h}$ by nitrate respiration. The initial cell density of the fresh suspension was about $25 \%$ of the cell density level of the preculture. Figure 1 shows the kinetics of cell growth and changes in SOD or MV-NaR activities during the anaerobic culture by nitrate respiration. MV-NaR activity increased with little lag and after $2 \mathrm{~h}$ the activity reached almost the same level as the cells grown

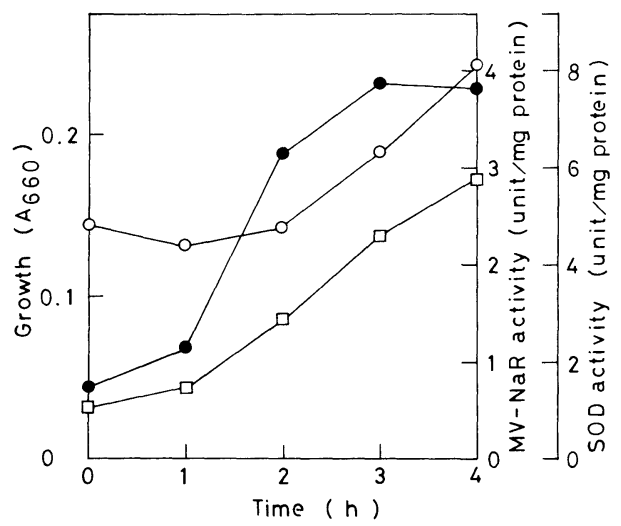

Fig. 1. Kinetics of anaerobic synthesis of enzymes in E. coli.

Cells cultured anaerobically for $18 \mathrm{~h}$ without $\mathrm{KNO}_{3}$ were harvested, suspended in fresh medium and cultured anaerobically for $4 \mathrm{~h}$ with $40 \mathrm{~mm} \mathrm{KNO}_{3}$. Growth ( $\square$ ), MVNaR activity $(\bullet)$ and SOD activity $(O)$. 
anaerobically for $18 \mathrm{~h}$ by nitrate respiration. During the culture, SOD activity started to increase after a $2 \mathrm{~h}$ lag and after growth for $4 \mathrm{~h}$ the SOD activity reached only $35 \%$ of the cells grown anaerobically for $18 \mathrm{~h}$ by nitrate respiration. In the cells grown anaerobically for $4 \mathrm{~h}$ by nitrate respiration, Fe SOD was detected but Mn SOD and hybrid SOD were not detected by gel electrophoresis (data not shown).

\section{Induction of SOD separated from the induction of nitrate respiration system}

We attempted to develop a system with which SOD is induced independently of the induction of the nitrate respiration system. The results in Fig. 1 show that when cells were cultured anaerobically for $2 \mathrm{~h}$ with $40 \mathrm{mM} \mathrm{KNO}_{3}, \mathrm{MV}-\mathrm{NaR}$ is almost fully induced but SOD remained at the original level. Therefore, cells, cultured anaerobically for $2 \mathrm{~h}$ with $40 \mathrm{~mm} \mathrm{KNO}_{3}$ and already contained a high level of MV-NaR, were harvested, washed and suspended in a mixture containing $0.25 \%$ casamino acids, $10 \mu \mathrm{M} \mathrm{FeCl}_{3}, 10 \mu \mathrm{M} \mathrm{MnSO}_{4}$ and $0.1 \mathrm{M}$ potassium phosphate buffer (pH 7.2), then incubated anaerobically for $4 \mathrm{~h}$ with or without additions such as nitrate or electron donors. The results in Fig. 2 show that when the cells were incubated anaerobically with $40 \mathrm{~mm} \mathrm{KNO}_{3}$ and $40 \mathrm{~mm}$ formate, only SOD was induced without alteration of the level of MV-NaR activity. Moreover, the level of the nitrate respiration system, from formate to nitrate, was not affected by chloramphenicol during the incubation,

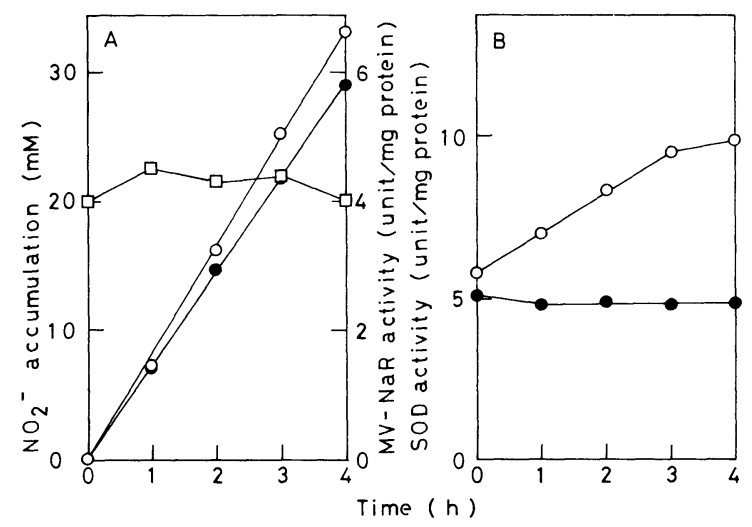

Fig. 2. Nitrite accumulation and SOD activity in resting cells of E. coli.

Cells, cultured anaerobically for $18 \mathrm{~h}$ without $\mathrm{KNO}_{3}$, were inoculated in the fresh medium containing $40 \mathrm{~mm} \mathrm{KNO}_{3}$ and cultured anaerobically for $2 \mathrm{~h}$. Then cells were harvested, washed once with $20 \mathrm{~mm}$ potassium phosphate buffer ( $\mathrm{pH} 7.2$ ), then suspended in the incubation mixture and incubated anaerobically for $4 \mathrm{~h}$. The composition of the incubation mixture was $40 \mathrm{~mm} \mathrm{KNO}_{3}, 40 \mathrm{~mm}$ formate, $10 \mu \mathrm{M} \mathrm{FeCl}_{3}, 10 \mu \mathrm{M} \mathrm{MnSO}_{4}, 0.25 \%$ casamino acids and $0.1 \mathrm{M}$ potassium phosphate buffer ( $\mathrm{pH} 7.2$ ).

A: Nitrite accumulation in the mixture during the incubation of cells without chloramphenicol $(\bigcirc)$ or with $200 \mu \mathrm{g} / \mathrm{ml}$ chloramphenicol $(\bullet)$. MV-NaR activity of the cells incubated without chloramphenicol $(\square)$. B: SOD activity of cells incubated without chloramphenicol (O) or with $200 \mu \mathrm{g} / \mathrm{ml}$ chloramphenicol (•). 
Table 1. Effect of chloramphenicol or rifampicin on anaerobic induction of SOD in E. coli by nitrate respiration.

\begin{tabular}{llrr}
\hline \multicolumn{2}{c}{ Additions to incubation mixture } & \\
Electron donor & Inhibitor & $\begin{array}{c}\text { Cell density } \\
\left(A_{660}\right)\end{array}$ & $\begin{array}{r}\text { SOD activity } \\
\text { (unit/mg protein) }\end{array}$ \\
\hline Formate $(40 \mathrm{~mm})$ & None & 0.321 & $11.8(2.2)^{b}$ \\
Formate $(40 \mathrm{~mm})$ & Chloramphenicol $(150 \mu \mathrm{g} / \mathrm{ml})$ & 0.216 & $6.9(1.0)$ \\
Formate $(40 \mathrm{~mm})$ & Rifampicin $(50 \mu \mathrm{g} / \mathrm{ml})$ & 0.177 & $7.3(0.9)$ \\
Glucose $(10 \mathrm{~mm})$ & None & 0.452 & $12.2(1.9)$ \\
Glucose $(10 \mathrm{~mm})$ & Chloramphenicol $(150 \mu \mathrm{g} / \mathrm{ml})$ & 0.211 & $5.9(0.6)$ \\
Glucose $(10 \mathrm{~mm})$ & Rifampicin $(50 \mu \mathrm{g} / \mathrm{ml})$ & 0.149 & $7.0(0.6)$ \\
Before incubation & & 0.257 & $6.3(0.6)$ \\
\hline
\end{tabular}

Cells were incubated as described in the legend to Fig. 2.

${ }^{a}$ The composition of the incubation mixture was $40 \mathrm{~mm} \mathrm{KNO}, 10 \mu \mathrm{M} \mathrm{FeCl}, 10 \mu \mathrm{M} \mathrm{MnSO}_{4}, 0.25 \%$ casamino acids and $0.1 \mathrm{M}$ potassium phosphate buffer $(\mathrm{pH} 7.2)$.

${ }^{b}$ Standard deviation.

Table 2. Anaerobic induction of SOD in E. coli by nitrate respiration.

\begin{tabular}{llcc}
\hline \multicolumn{2}{c}{ Additions to incubation mixture $^{a}$} & $\begin{array}{c}\text { Cell density } \\
\left(A_{660}\right)\end{array}$ & $\begin{array}{c}\text { SOD activity } \\
\text { (unit/mg protein) }\end{array}$ \\
\hline Electron donor & Electron acceptor & 0.210 & $4.5(1.0)^{b}$ \\
Formate $(40 \mathrm{~mm})$ & None & 0.215 & $4.3(1.2)$ \\
DL-Lactate $(40 \mathrm{~mm})$ & None & 0.197 & $5.7(1.3)$ \\
Glycerol $(40 \mathrm{~mm})$ & None & 0.420 & $4.7(1.0)$ \\
Glucose $(10 \mathrm{~mm})$ & $\mathrm{None}$ & 0.215 & $4.8(1.0)$ \\
None & $\mathrm{KNO}_{3}(40 \mathrm{~mm})$ & 0.317 & $7.7(1.8)$ \\
Formate $(40 \mathrm{~mm})$ & $\mathrm{KNO}_{3}(40 \mathrm{~mm})$ & 0.239 & $5.5(1.3)$ \\
DL-Lactate $(40 \mathrm{~mm})$ & $\mathrm{KNO}_{3}(40 \mathrm{~mm})$ & 0.338 & $8.8(1.0)$ \\
Glycerol $(40 \mathrm{~mm})$ & $\mathrm{KNO}_{3}(40 \mathrm{~mm})$ & 0.524 & $8.0(1.3)$ \\
Glucose $(10 \mathrm{~mm})$ & $\mathrm{KNO}_{3}(40 \mathrm{~mm})$ & 0.266 & $4.4(0.9)$ \\
Before incubation & & & 0.96 \\
\hline
\end{tabular}

Cells were incubated as described in the legend to Fig. 2.

${ }^{a}$ The composition of the incubation mixture was $0.25 \%$ casamino acids, $10 \mu \mathrm{M} \mathrm{FeCl}_{3}, 10 \mu \mathrm{M} \mathrm{MnSO}_{4}$ and $0.1 \mathrm{M}$ potassium phosphate buffer $(\mathrm{pH} 7.2)$.

${ }^{b}$ Standard deviation.

as shown by the fact that the inhibitor did not affect the rate of nitrite accumulation from nitrate and formate.

By using the method of incubation as shown in Fig. 2, it was possible to examine the effect of several factors on the synthesis of SOD by nitrate respiration. The results in Fig. 2B and Table 1 show that adding chloramphenicol or adding riphampicin inhibited SOD induction by nitrate respiration. The results in Table 2 show that both nitrate and some electron donor were required to induce SOD: among the donors tested, glucose, glycerol and formate were equally effective. In the 
Table 3. Effect of paraquat on anaerobic induction of SOD in E. coli by nitrate respiration.

\begin{tabular}{llccc}
\hline \multicolumn{2}{c}{ Additions to incubation mixture } & & \\
Electron donor & Electron acceptor & $\begin{array}{c}\text { Paraquat } \\
(\mathrm{mm})\end{array}$ & $\begin{array}{c}\text { Cell density } \\
\left(A_{660}\right)\end{array}$ & $\begin{array}{c}\text { SOD activity } \\
\text { (unit/mg protein) }\end{array}$ \\
\hline None & None & 0.5 & 0.188 & $3.9(0.8)^{b}$ \\
Formate $(40 \mathrm{~mm})$ & None & 0.5 & 0.180 & $4.0(0.8)$ \\
Glucose $(10 \mathrm{~mm})$ & None & 0.5 & 0.431 & $4.4(0.4)$ \\
None & $\mathrm{KNO}_{3}(40 \mathrm{~mm})$ & 0.5 & 0.212 & $4.1(1.1)$ \\
Formate $(40 \mathrm{~mm})$ & $\mathrm{KNO}_{3}(40 \mathrm{~mm})$ & 0.0 & 0.308 & $7.5(1.9)$ \\
Formate $(40 \mathrm{~mm})$ & $\mathrm{KNO}_{3}(40 \mathrm{~mm})$ & 0.5 & 0.271 & $6.3(1.5)$ \\
Glucose $(10 \mathrm{~mm})$ & $\mathrm{KNO}_{3}(40 \mathrm{~mm})$ & 0.0 & 0.507 & $8.9(2.0)$ \\
Glucose $(10 \mathrm{~mm})$ & $\mathrm{KNO}_{3}(40 \mathrm{~mm})$ & 0.5 & 0.482 & $8.0(1.7)$ \\
Before incubation & & & 0.268 & $4.1(1.0)$ \\
\hline
\end{tabular}

Cells were incubated as described in the legend to Fig. 2.

${ }^{a}$ The composition of the incubation mixture was $0.25 \%$ casamino acids, $10 \mu \mathrm{M} \mathrm{FeCl}_{3}, 10 \mu \mathrm{M} \mathrm{MnSO}_{4}$ and $0.1 \mathrm{M}$ potassium phosphate buffer $(\mathrm{pH} 7.2)$.

${ }^{b}$ Standard deviation.

Table 4. Effect of DCCD or FCCP on anaerobic induction of SOD in E. coli by nitrate respiration.

\begin{tabular}{llcr}
\hline \multicolumn{2}{c}{ Additions to incubation mixture $^{a}$} & $\begin{array}{c}\text { Cell density } \\
\left(A_{660}\right)\end{array}$ & $\begin{array}{c}\text { SOD activity } \\
\text { (unit/mg protein) }\end{array}$ \\
\hline Electron donor & Inhibitor & 0.335 & $9.6(0.8)^{b}$ \\
Formate $(40 \mathrm{~mm})$ & None & 0.181 & $5.4(0.8)$ \\
Formate $(40 \mathrm{mM})$ & DCCD $(100 \mu \mathrm{M})$ & 0.143 & $5.1(0.9)$ \\
Formate $(40 \mathrm{mM})$ & FCCP $(5 \mu \mathrm{M})$ & 0.402 & $8.7(0.9)$ \\
Glucose $(10 \mathrm{~mm})$ & None & 0.238 & $10.0(1.2)$ \\
Glucose $(10 \mathrm{~mm})$ & DCCD $(100 \mu \mathrm{M})$ & 0.184 & $5.7(0.9)$ \\
Glucose $(10 \mathrm{~mm})$ & FCCP $(5 \mu \mathrm{M})$ & 0.270 & $5.6(0.7)$ \\
Before incubation & & & \\
\hline
\end{tabular}

Cells were incubated as described in the legend to Fig. 2.

${ }^{a}$ The composition of the incubation mixture was $40 \mathrm{~mm} \mathrm{KNO}, 10 \mu \mathrm{M} \mathrm{FeCl}_{3}, 10 \mu \mathrm{M} \mathrm{MnSO}, 0.5 \%$ ethanol, $0.25 \%$ casamino acids and $0.1 \mathrm{~m}$ potassium phosphate buffer $(\mathrm{pH} 7.2)$. DCCD or FCCP was added as ethanol solutions.

$b$ Standard deviation.

system, only Fe SOD was synthesized but no Mn SOD or hybrid SOD (Fig. 3B, C).

\section{Effect of paraquat on anaerobic SOD synthesis}

Aerobic synthesis of Mn SOD and hybrid SOD was reported to be stimulated by adding paraquat (13). Therefore, the effect of paraquat on the anaerobic Fe SOD induction by nitrate respiration was examined. The results shown in Table 3 


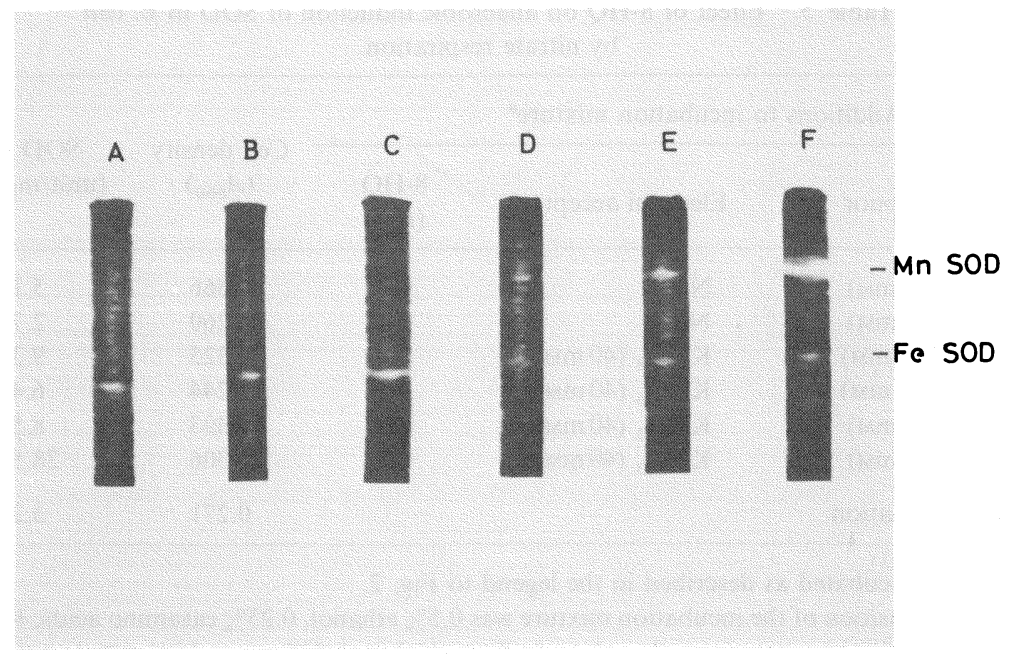

Fig. 3. SOD isozyme pattern in resting cells of $E$. coli.

Cells, cultured anaerobically for $2 \mathrm{~h}$ with $40 \mathrm{mM} \mathrm{KNO}_{3}$, were harvested and washed as shown in the legend to Fig. 2. The cells were suspended in an incubation mixture containing $0.25 \%$ casamino acid, $10 \mu \mathrm{M} \mathrm{FeCl}_{3}, 10 \mu \mathrm{M} \mathrm{MnSO}_{4}$ and $0.1 \mathrm{M}$ potassium phosphate buffer ( $\mathrm{pH}$ 7.2) and incubated anaerobically for $4 \mathrm{~h}$ with the following additions: B, $40 \mathrm{~mm} \mathrm{KNO}_{3}$ and $40 \mathrm{~mm}$ formate; $\mathrm{C}, 40 \mathrm{~mm} \mathrm{KNO}_{3}$ and $10 \mathrm{~mm}$ glucose; $\mathrm{D}$, $10 \mathrm{~mm}$ glucose and $0.5 \mathrm{~mm} 8-\mathrm{HQ}$; E, $40 \mathrm{~mm} \mathrm{KNO}_{3}, 40 \mathrm{~mm}$ formate and $0.5 \mathrm{~mm} 8-\mathrm{HQ}$; F, $40 \mathrm{mM} \mathrm{KNO}_{3}, 10 \mathrm{~mm}$ glucose and $0.5 \mathrm{~mm} 8-\mathrm{HQ}$. Gel A was before incubation.

Cells were disrupted and the SOD isozyme pattern was detected by gel electrophoresis.

indicate that adding paraquat had no effect on Fe SOD induction by nitrate respiration.

\section{Effect of DCCD or FCCP on anaerobic SOD induction by nitrate respiration}

Nitrate respiration in $E$. coli generates a transmembrane proton motive force, and ATP is synthesized by proton-translocating adenosine triphosphatase $\left(\mathrm{H}^{+}\right.$ATPase) (14). Carbonyl cyanide $p$-trifluoro-methoxyphenyl-hydrazone (FCCP) is an uncoupler of oxidative phosphorylation and $N, N^{\prime}$-dicyclohexylcarbodiimide (DCCD) binds to a specific protein moiety of $\mathrm{H}^{+}$-ATPase. In the present study, the effects of these inhibitors on anaerobic induction of Fe SOD by nitrate respiration were studied. When glucose was used as the electron donor, FCCP but not DCCD inhibited the anaerobic Fe SOD induction by nitrate respiration. When formate was used as the donor, not only FCCP but also DCCD inhibited the anaerobic Fe SOD induction by nitrate respiration (Table 4).

Effect of iron chelators on anaerobic SOD synthesis

Moody and Hassan (15), Pugh and Fridovich (16) reported that removal of 
Table 5. Effect of 8-HQ on anaerobic induction of SOD in E. coli by nitrate respiration.

\begin{tabular}{|c|c|c|c|c|}
\hline \multicolumn{3}{|c|}{ Additions to incubation mixture ${ }^{a}$} & \multirow{2}{*}{$\begin{array}{l}\text { Cell density } \\
\quad\left(A_{660}\right)\end{array}$} & \multirow{2}{*}{$\begin{array}{c}\text { SOD activity } \\
\text { (unit/mg protein) }\end{array}$} \\
\hline Electron donor & Electron acceptor & $\begin{array}{l}\text { 8-HQ } \\
(\mathrm{mM})\end{array}$ & & \\
\hline Glucose (10 mм) & None & 0.0 & 0.366 & $5.1(0.5)^{b}$ \\
\hline Glucose (10 mм) & None & 0.5 & 0.260 & $2.7(0.8)$ \\
\hline Formate $(40 \mathrm{~mm})$ & $\mathrm{KNO}_{3}(40 \mathrm{~mm})$ & 0.0 & 0.325 & $9.3(1.1)$ \\
\hline Formate $(40 \mathrm{~mm})$ & $\mathrm{KNO}_{3}(40 \mathrm{~mm})$ & 0.5 & 0.244 & $6.4(0.8)$ \\
\hline Glucose (10 mм) & $\mathrm{KNO}_{3}(40 \mathrm{~mm})$ & 0.0 & 0.393 & $8.5(1.1)$ \\
\hline Glucose (10 mm) & $\mathrm{KNO}_{3}(40 \mathrm{~mm})$ & 0.5 & 0.306 & $28.5(4.8)$ \\
\hline Before incubation & & & 0.271 & $5.2(0.7)$ \\
\hline
\end{tabular}

Cells were incubated as described in the legend to Fig. 2.

${ }^{a}$ The composition of the incubation mixture was $0.5 \%$ ethanol, $0.25 \%$ casamino acids, $10 \mu \mathrm{M} \mathrm{FeCl}_{3}$, $10 \mu \mathrm{M} \mathrm{MnSO}_{4}$ and $0.1 \mathrm{~m}$ potassium phosphate buffer ( $\mathrm{pH}$ 7.2). 8-HQ was added as ethanol solutions.

b Standard deviation.

iron from culture media induced the synthesis of Mn SOD under anaerobic conditions. Therefore, the effect of iron chelators on anaerobic induction of SOD by nitrate respiration was examined. Adding 8-hydroxyquinoline (8-HQ) induced anaerobic Mn SOD synthesis even when cells were incubated in the absence of nitrate (Fig. 3D). Nitrate respiration further stimulated anaerobic Mn SOD synthesis by 8-HQ, while the amount of Fe SOD decreased by 8-HQ even with nitrate respiration (Fig. 3E, F). Only when cells were incubated with glucose and nitrate, the total level of SOD increased by 8 -HQ (Table 5).

\section{DISCUSSION}

The results shown in Figs. 2 and 3 show that Fe SOD was increased by nitrate respiration without alteration of the nitrate respiration system. During the incubation of cell suspensions by using formate as the electron donor for nitrate respiration, the increase of cell density was only $25 \%$ of the original density, while the specific activity of SOD increased to about twice the original activity. A twofold increase of cell density occurred when glucose is used as the electron donor. We are developing a system, in which glucose is used as the electron donor but the increase of cell density is less than $15 \%$ of the original density; with this system, SOD activity was increased about twofold by nitrate respiration (data not shown).

The anaerobic induction of Fe SOD required both nitrate and an electron donor (Table 2). Chloramphenicol or riphampicin inhibited the Fe SOD induction by nitrate respiration (Table 1). These results show that nitrate respiration induce de novo synthesis of Fe SOD.

Anaerobic Mn SOD synthesis by adding an iron chelator occurred even when 
cells were incubated with glucose alone (Fig. 3D), but the anaerobic Mn SOD synthesis by adding iron chelator was further stimulated by nitrate respiration (Fig. $3 \mathrm{E}, \mathrm{F})$. Therefore, the anaerobic Mn SOD synthesis by iron chelator is partially dependent on nitrate respiration.

The results in Table 4 show that FCCP inhibited Fe SOD induction by nitrate respiration whether the electron donor was formate or glucose. When formate was used as the electron donor in nitrate respiration, that is, when ATP was generated only through the electron transport system, DCCD inhibited anaerobic Fe SOD induction, but when glucose was used as the donor, that is, when ATP was generated by both fermentative and electron transport systems, DCCD did not inhibit the anaerobic Fe SOD induction. These results indicate that both ATP and proton motive force are required to induce Fe SOD by nitrate respiration.

PugH et al. reported that the enrichment of the medium with ferrous ion elevated the Fe SOD in aerobically grown E. coli(17). LODGE and EMERY reported that anaerobic ferrienterobactin transport in E. coli cells, grown anaerobically with nitrate, was inhibited by $\mathrm{KCN}$ or by dinitrophenol (18).

These results indicate that the uptake of iron is stimulated by the operation of nitrate respiration. If so, the relationship between intracellular $\mathrm{Fe}$ ion and the induction of Fe SOD by nitrate respiration is not yet clear. Some models to explain the regulation of anaerobic Mn SOD synthesis were proposed $(7,15,16,19)$, but a model to explain the regulation of anaerobic Fe SOD synthesis has not been proposed. More studies are necessary to elucidate the mechanism of Fe SOD synthesis by nitrate respiration.

\section{REFERENCES}

1) F. J. Yost, Jr. and I. Fridovich, J. Biol. Chem., 248, 4905 (1973).

2) B. B. Keele, Jr., J. M. MCCord, and I. Fridovich, J. Biol. Chem., 245, 6176 (1970).

3) H. W. Dowgherty, S. J. SAdowski, and E. Baker, J. Biol. Chem., 253, 5220 (1978).

4) K. Miyake, J. Gen. Appl. Microbiol., 32, 527 (1986).

5) K. Miyake and S. Hino, J. Gen. Appl. Microbiol., 34, 105 (1988).

6) H. M. Hassan and C. S. Moody, J. Biol. Chem., 262, 17173 (1987).

7) J. R. Schiavone and H. M. Hassan, J. Biol. Chem., 263, 4269 (1988).

8) C. T. Privalle and I. Fridovich, J. Biol. Chem., 263, 4274 (1988).

9) J. M. MCCord and I. Fridovich, J. Biol. Chem., 244, 6049 (1969).

10) C. Beauchamp and I. Fridovich, Anal. Biochem., 44, 276 (1971).

II) D. K. Gauthier, G. D. Clark-Waker, W. T. Garrard, Jr., and J. Lascelles, J. Bacteriol., 102. 797 (1970).

12) R. F. Itzhaki and D. M. Gill, Anal. Biochem., 9, 401 (1964).

13) H. M. Hassan and I. Fridovich, J. Biol. Chem., 252, 7667 (1977).

14) W. J. Ingledew and R. K. Poole, Microbiol. Rev., 48, 222 (1984).

15) C. S. Moody and H. M. Hassan, J. Biol. Chem., 259, 12821 (1984).

16) S. Y. R. Pugh and I. Fridovich, J. Bacteriol., 162, 196 (1985).

17) S. Y. R. Pugh, J. L. Diguiseppi, and I. Fridovich, J. Bacteriol., 160, 137 (1984).

18) J. S. Lodge and T. Emery, J. Bacteriol., 160, 801 (1984).

19) P. R. Gardner and I. Fridovich, J. Biol. Chem., 262, 17591 (1987). 